\title{
Formulating Digital Strategy Using Design Thinking Approach at Eguards
}

\author{
Bayu Waspodo ${ }^{1}$, A 'ang Subiyakto ${ }^{2}$, Rinda Hesti $\mathrm{K}^{3}$, Zulfiandri ${ }^{4}$, \\ Garda Prakoso Aji ${ }^{5}$, Husni Teja Sukmana ${ }^{6}$ \\ \{bayu.waspodo@uinjkt.ac.id ${ }^{1}$, aang_subiyakto@uinjkt.ac.id ${ }^{2}$, rinda.hesti@uinjkt.ac.id ${ }^{3}$, \\ zulfiandri@uinjkt.ac.id ${ }^{4}$, garda.aji14@mhs.uinjkt.ac.id ${ }^{5}$, husniteja@uinjkt.ac.id ${ }^{6}$ \} \\ Sy arif Hiday atullah State Islamic University of Jakarta, Indonesia ${ }^{123456}$
}

\begin{abstract}
Eguards are newly established startups that provide on-demand online security. It's still difficult to be able to develop the potential of existing resources and trying to improve customer brand awareness. Therefore, research being conducted on digital strategy planning. This digital strategy planning uses the Design Thinking approach supported by an analysis of the Platform Design Toolkit. This digital strategy planning focuses on analyzing platforms from the customer side of Eguards. The data collection method is carried out through literature study, observation, and interviews conducted at Eguards startup and Eguards user questionnaire. The results of this research are in the form of three suggested features that researchers propose in this research which are intended to increase the ease of Eguards application users, namely the "chat-on apps" feature, the feature can see the coverage of the Eguards service area and the feature of adding payment methods.
\end{abstract}

Keywords: Digital Strategy Planning, Design Thinking, Design Toolkit, Digital Platform, Startup.

\section{Introduction}

The information system is expected to help the performance of agencies in obtaining the information needed by using information technology.

It can be seen that IS / IT has several important roles in an organization, among others, IS / IT is a means to assist an organization in achieving efficient integration between management and operational perspectives (back office and front office process), improve the quality of service to consumers, IS / IT can also be used as a basis to help decision making. Also, IS / IT can assist an organization in planning future work programs or in general, it can be said that IS / IT functions as a means of assisting the organization in realizing its strategic objectives [1].

The main cause of an organization's failure to implement IS / IT is the lack of careful planning of IS / IT implementation. [1]. Planning for IS / IT implementation must be aligned between the IS / IT strategy and the IS / IT strategy. Strategic planning for IS / IT is necessary for any organization that will utilize IS / IT. This document is a reference to investing in IS / IT. Without clear planning, the IS / IT investment that will be carried out will run without direction, contributing that is not optimal and not aligned with the objectives to be achieved [2]. 
In a business or company in the digital era, digital capabilities are quite able to drive the progress of a company by utilizing easily accessible technologies such as SMACIT (Social, Mobile, Analytics, Cloud, and Internet of Things) [3] that presents a great opportunity for companies to compare the value propositions, especially combining existing competencies with technological capabilities [4].

Indonesia currently has 2.152 digital startups. In the past year, Indonesia recorded a growth of around 200 startups, from 1.940 startups in 2018. This condition puts Indonesia in the fifth position as the country with the largest number of startups in the world. Based on these data, Indonesia only lost to the United States which had 47.212 startups, India 6.856 startups, British 5.037 startups, and Canada 2.557 startups. Indonesia is far superior compared to Australia which ranks 7 th with 1.540 startups and Singapore which ranks 14th with 700 startups [5].

Faced with a large degree of uncertainty and risk, many startup companies are not able to plan through thought and strategic planning. Even though the survival rate of startup businesses is only $50 \%$ in the first 5 years, many of the business owners believe that a strategic plan is unnecessary and too difficult to implement. However, several studies have shown that small and medium scale companies that formulate strategies can outperform their competitors [6].

The number of startups that continues to grow every year makes a startup company in this case Eguards which are the object of research from researchers are required to continue to improve the quality and ease of service and continue to innovate to win the competition. Eguards, which is one of the new startups, found it still difficult to be able to develop the potential of existing resources, besides that Eguards was still trying to increas e customer brand awareness. These deficiencies can have an impact on competition between competitors and the survival of the company.

From the background explanation above and the literature references that researchers read, the role of digital strategy planning is needed by a startup company to be able to align business strategies with IS / IT strategies to support each other and is also one of the keys to achieving vision and company mission. This digital strategy planning uses the Design Thinking approach supported by the Platform Design Toolkit.

\section{Literature Review}

An information system is a collection of interacting components to collect, store, process, provide information that can help an organization achieve its objectives [7].

An information system is a system within an organization that meets the needs of daily transaction processing that supports the organization's managerial operational functions with the strategic activities of an organization to be able to provide reports needed by certain external parties [8].

Briefly Haag and Ken (1996) define information technology as a set of tools that assist you in working with information and performing tasks related to information processing [9].

Digital strategy planning takes perspective and pursues different goals. The focus of this strategy is the changes in products, processes, and aspects of the organization due to new technology [10].

A digital strategy is a strategy that can help a company to improve competitiveness and increase profits by utilizing information systems and information technology [1]. 
Design Thinking is a discipline that uses designer sensibility and methods to match people's needs with what is technologically feasible and what is appropriate according to the business strategy can be transformed into customer value and market opportunities [11].

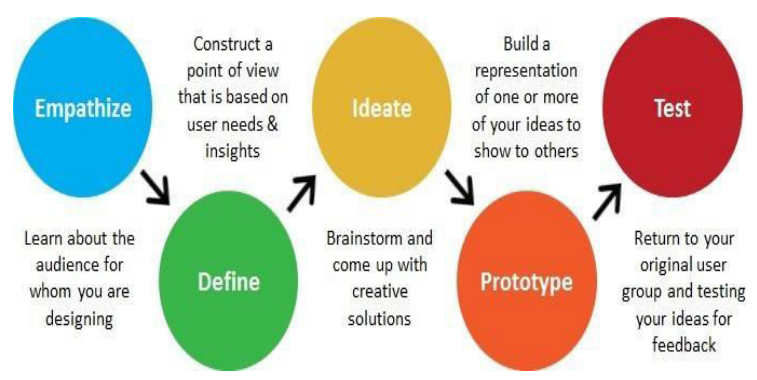

Fig. 1. Design Thinking Process [11].

The Platform Design Toolkit is a set of design thinking and canvas modeling systems to help design digital and non- digital platforms. The platform here is intended as a tool to help companies access the strengths that exist in the ecosystem and achieve goals that go far beyond their limits and potential as a single company [12].

The platform is any hardware or software whose function is used to Host an Application or Service. Application platforms, for example, consist of hardware, operating systems, and coordinating programs that use instruction sets for specific processors or microprocessors. In this case, the Platform creates a foundation that ensures object code will be executed successfully [13].

A startup is a company formed by humans to create something new with extreme conditions and calmness. It doesn't say about how big the company or what industry sector is, it just says we only try to build companies when we don't know what we don't know [14].

A startup is a company that is designed to develop quickly. Startups do not have to be engaged in technology and obtain funds from investors. The most important thing is the rapid development of the company, all matters relating to startup will follow the development of the company [15].

\section{Research Methodology}

In this research, researchers used two main methods, namely data collection methods and digital strategy planning methods. The data collection method is carried out in four stages, i.e.:

\subsection{Observation}

The observation was carried out by looking directly at the business processes and activities that are running at startup Eguards. This activity aims to see the business processes that occur, operational activities that occur, and find data needed for research. 


\subsection{Literature Review}

Researchers collected various information relating to this research. This information was sourced from various literary sources related to the research the researchers carried out.

\subsection{Interview}

Interviews in this study were conducted for data collection conducted through face to face and question and answer between researchers and related divisions, such as with the CEO, COO, and CTO. From interviews conducted it can be seen how the conditions of resources, information systems, information technology, and infrastructure that exist in Eguards.

\subsection{Questionnaire}

The questionnaire is aimed at Eguards users, aims to obtain habits or behavior of Eguards users and responses to the proposed features to be developed. The questionnaire is divided into three stages, in the first stage, the questionnaire contains questions about user habits or behavior in using the Eguards application, in the second stage contains questions about user responses about application features that will be proposed by researchers, and in the third stage contains questions about user responses to prototype display proposed features that have been made.

For digital strategy planning methods are divided into two stages, namely internal business analysis and external business analysis.

\subsubsection{Internal Digital Business Analysis}

Internal business analysis is carried out to determine the running digital business conditions and the business strategies adopted. Internal business analysis using the help of the Platform Design Toolkit.

\subsubsection{External Digital Business Analysis}

External business analysis is conducted to determine the company's external digital conditions that affect the course of the company. In this case, the researcher focuses on Eguards users as the external side of the company. The external business analysis uses the help of a Design Thinking approach.

The Design Thinking stages in this study include Empathize, which is to empathize with users, in other words, the researcher listens to the wishes of startup users Eguards. Then Define, the researcher defines the hopes and desires of the user. Input from the users was then used as an idea (Ideate) to develop products or services at startup Eguards. In the next stage, namely Prototype, researchers provide an overview or proposal on the product or service based on user feedback. Then test a prototype that was previously made to get feedback. 


\section{Result}

\subsection{Internal Digital Business Analysis}

\subsubsection{Design Toolkit Platform}

Design Toolkit is a design framework that can be used to imagine, develop, and launch platform strategies that mobilize ecosystems. The Toolkit is made of a series of design canvases plus additional resources.

\subsubsection{Ecosystem Canvas Analysis.}

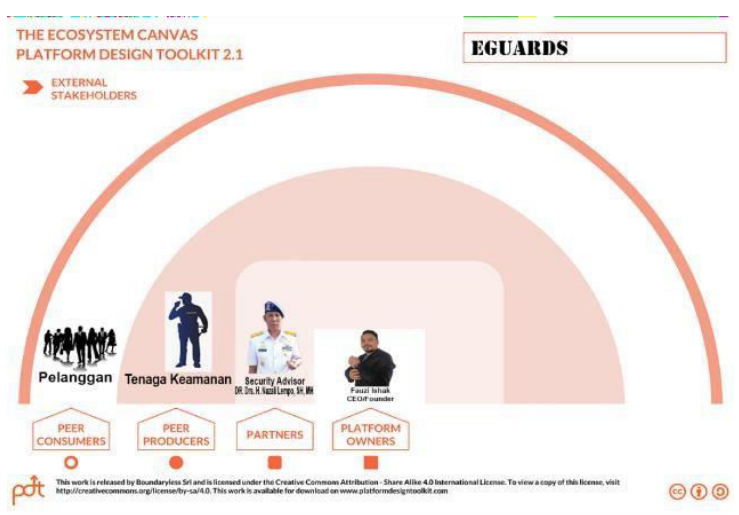

Fig. 2. Ecosystem Canvas

Figure 3 is a canvas of ecosystems that exist and play a role in companies, in Eguards there are four types of entities that have attributes in them.

\subsubsection{Ecosystem Entity Portrait Analysis.}

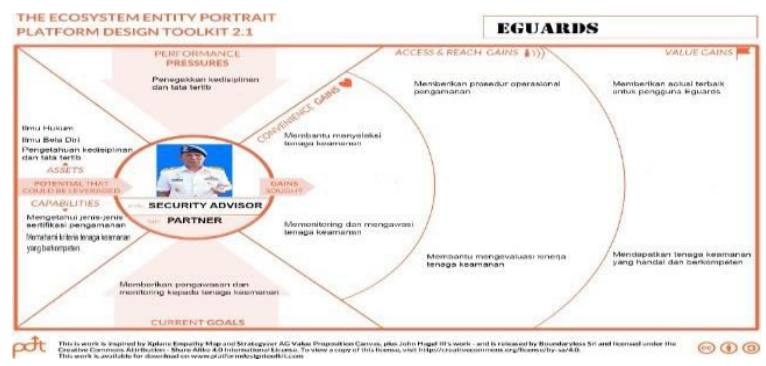

Fig. 3. Ecosy stem Entity Portrait

The picture above is a canvas of one of the entities in the ecosystem canvas, the analysis conducted focuses on the entity that plays an important role in collaborating with the Eguards in carrying out its business processes, namely Partners who act as Security Advisors. 


\subsubsection{Ecosystem's Motivation Matrix Analysis.}

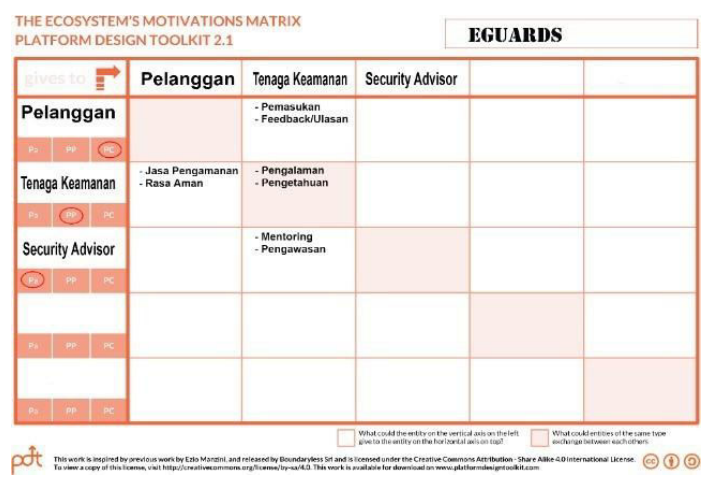

Fig. 4. Ecosy stem's Motivation Matrix

The picture above is an ecosystem motivational matrix, which shows what relationships are given from one entity to another, the relationships provided in the form of exchange of values from each entity. There are PC (Peer Consumers), PP (Peer Producers), PA (Partners) labels describing the role of each entity in the ecosystem.

\subsubsection{Transactions Board Analysis.}

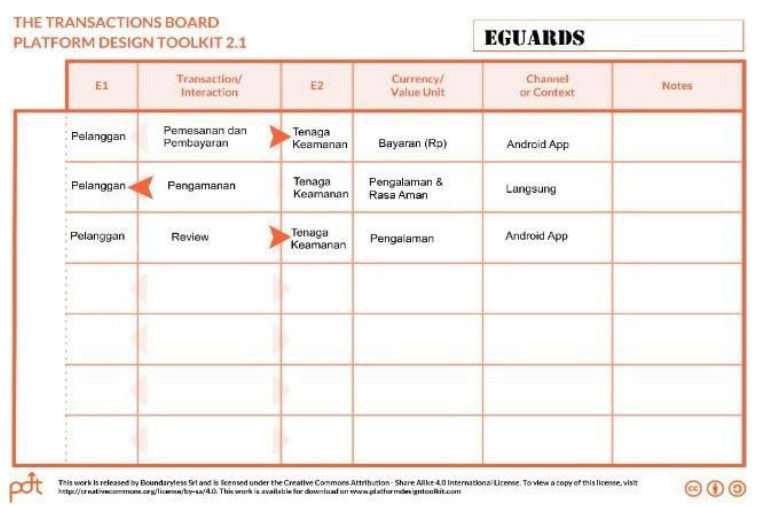

Fig. 5. Transactions Board

The picture above is a transaction board that explains transactions or interactions that occur between entities, this transaction board als o explains what value is obtained from that interaction and where or through what transaction or interaction took place. 


\subsubsection{Platform Experience Canvas Analysis.}

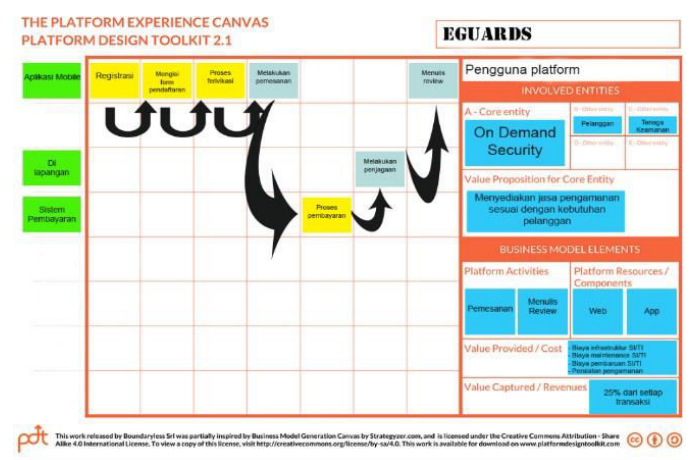

Fig. 6. Platform Experience Canvas

Images on the experience canvas on the platform, this canvas depicts the important phases of the platform by explaining the business model, the resources. components and costs incurred and obtained by Eguards.

\subsubsection{Minimum Viable Platform Canvas Analysis.}

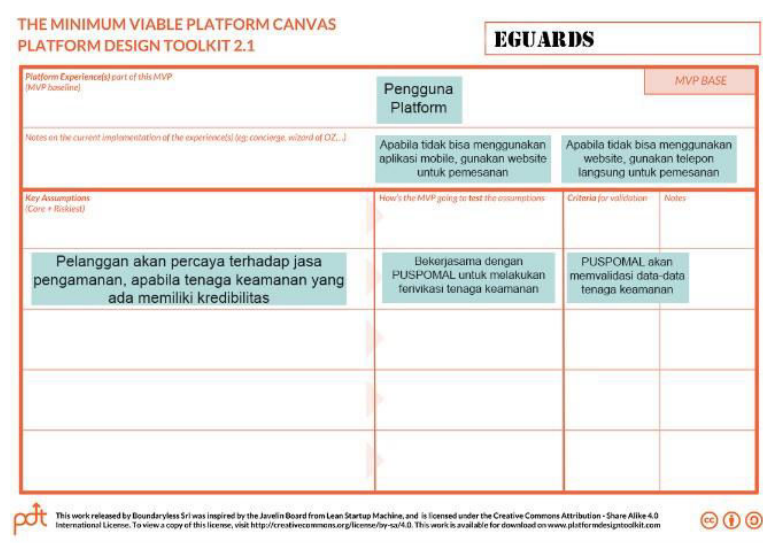

Fig. 7. Minimum Viable Platform Canvas

The picture above is a transaction board that explains transactions or interactions that occurs between entities, this transaction board also explains what value is obtained from that interaction and where or through what transaction or interaction takes place. 


\subsubsection{Platform Design Canvas Analysis.}

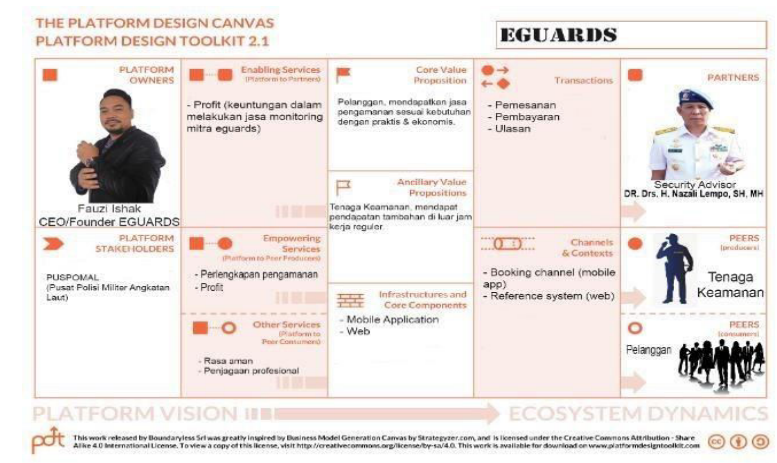

Fig. 8. Platform Design Canvas

Figure 8 is a platform design canvas, explains the overall analysis of the toolkit design, is a summary of the overall toolkit design canvas that has been collected, and describes each of the existing entities and relationships between entities.

\subsection{External Digital Business Analysis}

This study uses the stages that exist in Design Thinking.

\subsubsection{Empathize Phase.}

This empathizing phase aims to observe user experiences and their habits. The researcher made observations using a questionnaire to external parties, namely the Eguards application user, at this stage the researcher focused the user's response on the Eguards service namely:

- How long have users been using the Eguards application, how often have users used the Eguards application?

- Does the user use other similar applications besides the Eguards application as well as the reason the user prefers the Eguards application compared to other applications? What services are used by Eguards users and the availability of users in providing their data?

The following are the results of the questionnaire from some of the questions the researchers did. 
1. The results of the long measurement of using Eguards application

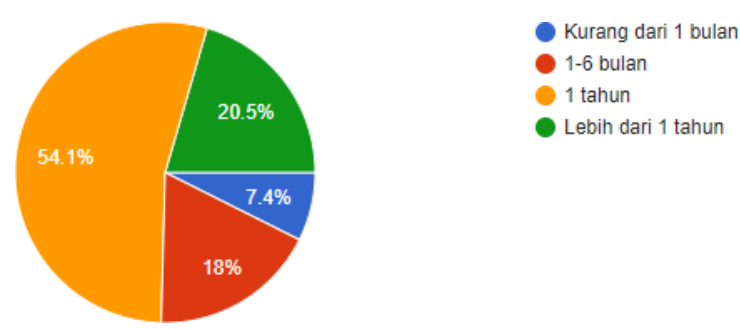

Fig. 9. Questionnaire Results Diagram

2 The results measure how often you use the Eguards application

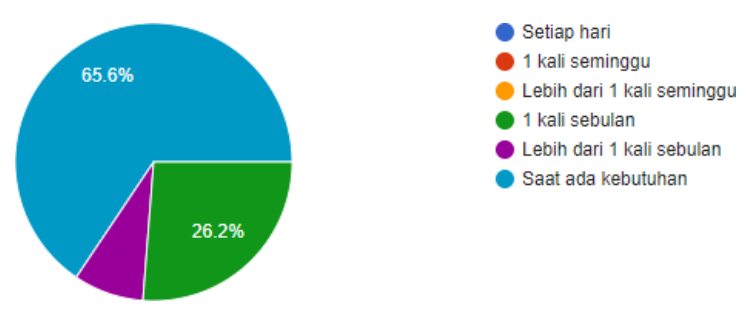

Fig. 10. Questionnaire Results Diagram

3. The results measure the use of applications other than Eguards

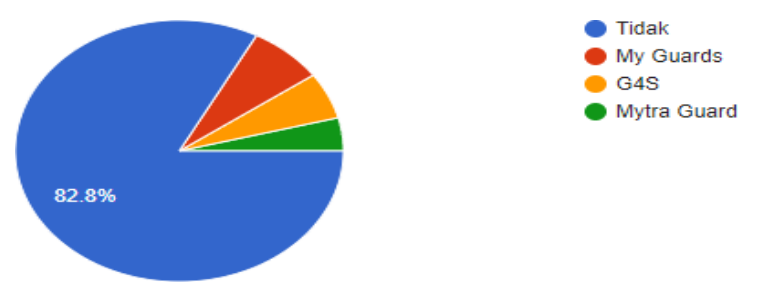

Fig. 11. Questionnaire Results Diagram

4. The results measure the reason for choosing the Eguards application

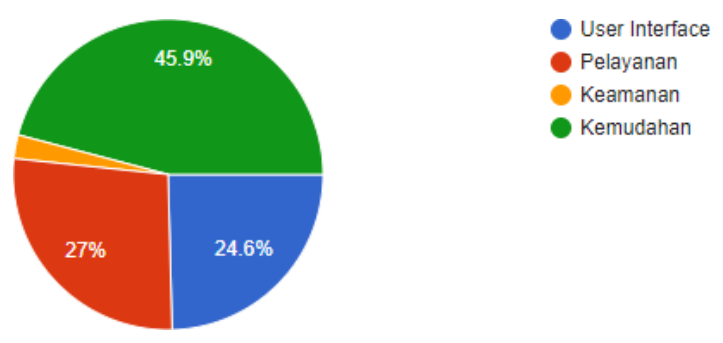

Fig. 12. Questionnaire Results Diagram 
5. The results of the availability measure provide a user's personal data

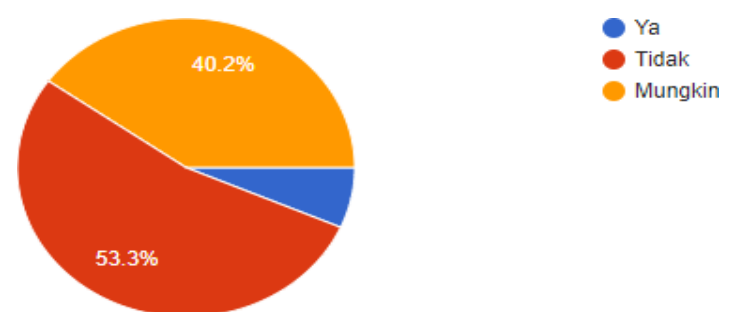

Fig. 13. Questionnaire Results Diagram

6 The result of the service size that is often used

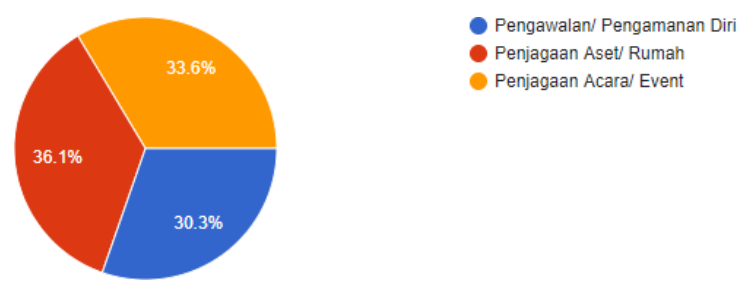

Fig. 14. Questionnaire Results Diagram

The conclusion of the questionnaire results obtained by researchers from Eguards users is: The service most frequently used by users is custody of assets or houses.

- More users do notagree to provide their data.

- More Eguards users do not use other applications even though there are other similar applications such as My Guards, G4S, and Mytra Guard. The reason users prefer Eguards compared to other applications is the reason for convenience.

- Most Eguards users have used the application for one year with most respondents using the application when there is a need.

From the above points, it can be concluded that Eguards need to focus on updating their applications that provide convenience to users because the biggest reason users choose the Eguards application compared to other applications is ease.

\subsubsection{Define Phase.}

In this phase, the researcher makes observations on the company to get how the business is run, as well as what are the important things so that Eguards can move the business.

A. Eguards Market Target

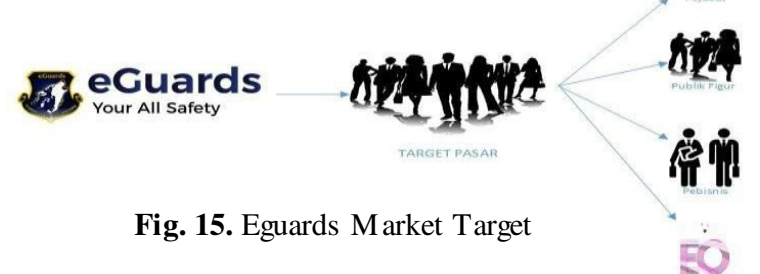

Fig. 15. Eguards Market Target 
B. Eguards Business Support

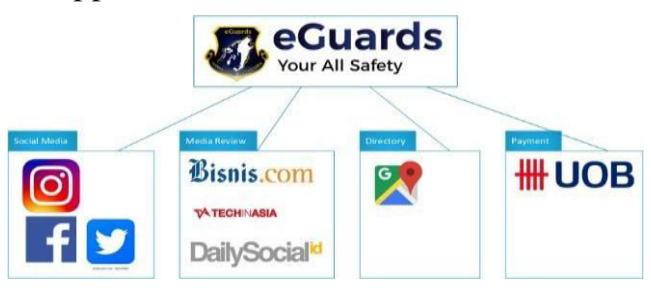

Fig. 16. Eguards Business Support

C. Eguards Concept Business

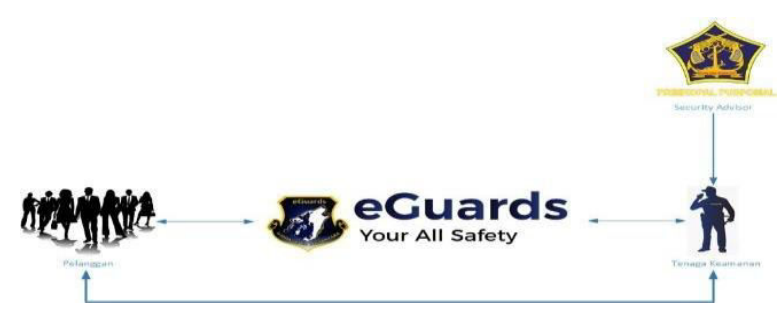

Fig. 17. Eguards Concept Business

After elaborating on the results of observations in the company and interviews with relevant parties, researchers found several problems that were felt from the user's side of the existing Eguards application, namely:

- After getting security personnel who will be on duty, customers are given detailed information on security personnel including contacts who can be contacted via email manually.

- Not all regions in JABODETABEK have been covered by Eguards service, so customers are still confused about whether there are Eguards services.

- The Eguards payment method is currently only available via UOB bank transfer.

\subsubsection{Ideate Phase}

From the problems that have been found in the previous phase, researchers make solutions and are presented in the table of problems and solutions below. 
Table 1. Problem and solutions.

\begin{tabular}{|c|c|}
\hline Problems & Solutions \\
\hline $\begin{array}{l}\text { How to keep customers } \\
\text { loyal and not move to } \\
\text { other competitors. }\end{array}$ & $\begin{array}{l}\text { By developing application } \\
\text { features to provide } \\
\text { convenience for each } \\
\text { transaction (solutions } \\
\text { based on the results of the } \\
\text { questionnaire user } \\
\text { responses eguards). }\end{array}$ \\
\hline $\begin{array}{l}\text { Customers are still given } \\
\text { detailed security personnel } \\
\text { information including } \\
\text { contacts that can be } \\
\text { contacted via email } \\
\text { manually. }\end{array}$ & $\begin{array}{l}\text { Creating features that } \\
\text { enable customers and } \\
\text { security personnel on } \\
\text { duty can be connected to } \\
\text { each other on the platform. }\end{array}$ \\
\hline $\begin{array}{l}\text { The customer is still } \\
\text { confused whether the area } \\
\text { already has Eguards } \\
\text { service or not. }\end{array}$ & $\begin{array}{l}\text { Create the Eguards area } \\
\text { coverage feature in the } \\
\text { GMaps column. }\end{array}$ \\
\hline $\begin{array}{l}\text { The Eguards payment } \\
\text { method is currently only } \\
\text { available via UOB bank } \\
\text { transfer. }\end{array}$ & $\begin{array}{l}\text { Providing other pay ment } \\
\text { methods. }\end{array}$ \\
\hline
\end{tabular}

From the description of the problems and solutions that have been outlined in the above table, the authors propose many suggested features to Eguards users through a questionnaire for future application development as follows. 
1. User response to the addition of the "Chat-on Apps" feature

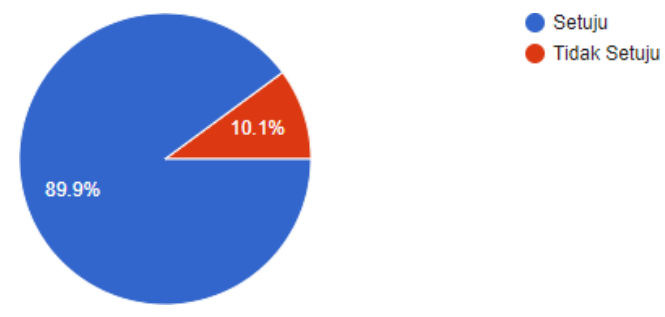

Fig. 18. Questionnaire Results Diagram

2 User response to be able to see the coverage area of the Eguards service in the "Google Maps" column

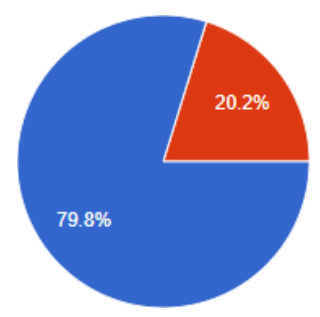

Setuju

Tidak Setuju

Fig. 19. Questionnaire Results Diagram

3. User response to adding other payment methods

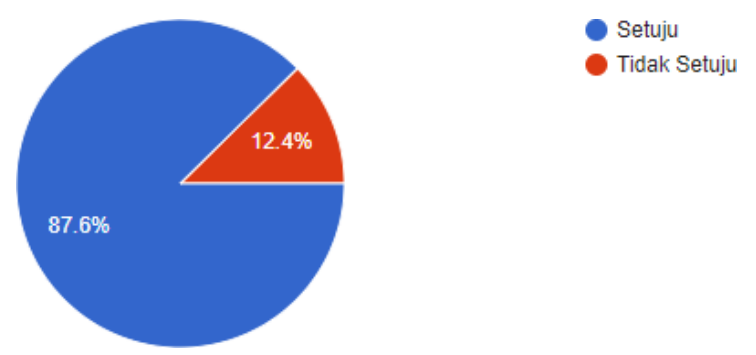

Fig. 20. Questionnaire Results Diagram

From the description above on the platform side, the researcher will design a feature that functions to strengthen the solution that has been given, to be applied to the Eguards mobile application, as follows:

- Chat-on apps. This feature is available if the customer's order has been verified by Eguards and has obtained security personnel who are ready to serve. The concept of this feature is the reciprocated message feature as found in the Go-Jek and Grab applications.

- Eguards area coverage. This feature appears in the Google Maps column in the initial order menu. Describe the scope of the area that already has Eguards services. 
- Other payment methods. This feature is an addition to the payment options that are currently available.

\subsubsection{Prototype Phase}

In this phase the researchers designed the prototype display of the Eguards mobile application using the Moqups tools, the display design at this stage followed the proposed feature solution which was the solution in the previous stage.

A. Prototype Display of Chat on App

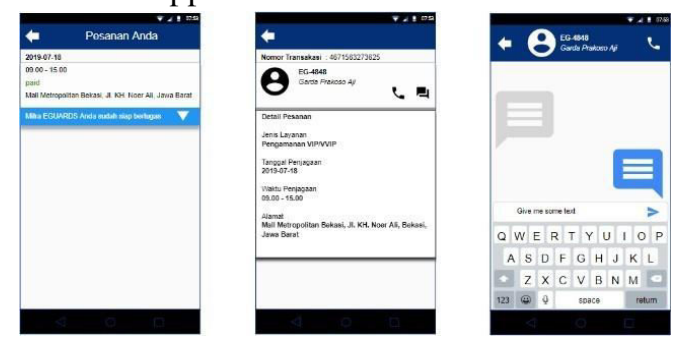

Fig. 21. Prototy pe Display Of Chat on App

B. Prototype Display of Eguards Territory

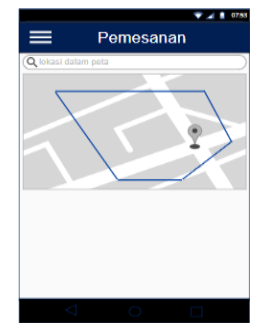

Fig. 22. Prototy pe display of Eguards territory

C. Prototype Display of Other Payment Methods
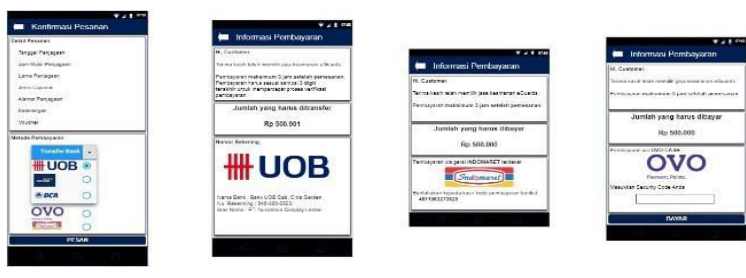

Fig. 23. Prototy pe Display of Other Payment Methods 


\subsubsection{Test Phase}

This phase is a continuation phase from the previous phase where the prototype display that has been previously made is tested by asking the Eguards user to respond to the results of the prototype display through a questionnaire.

1. User responses to the prototype "Chat on App"

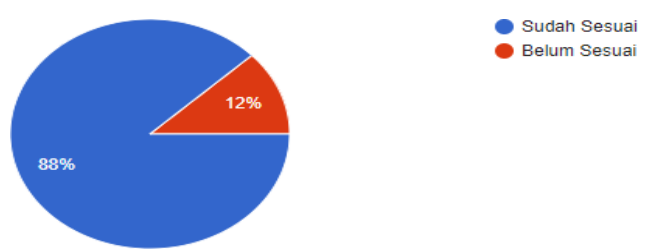

Fig. 24. Questionnaire Results Diagram

Figure 24 above is the result of user responses to the prototype of the "Chat on App" feature, where there are $88 \%$ of users who choose to be suitable and $12 \%$ are not.

2 User response to prototype coverage of the Eguards area

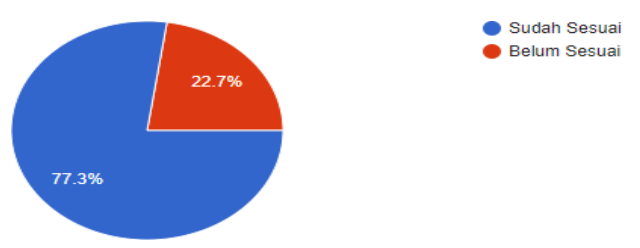

Fig. 25. Questionnaire Results Diagram

The picture above is the result of the user's response to the prototype coverage of the Eguards area, where $77.3 \%$ of users chose it accordingly and $22.7 \%$ did not match.

3. User responses to prototypes of other payment methods

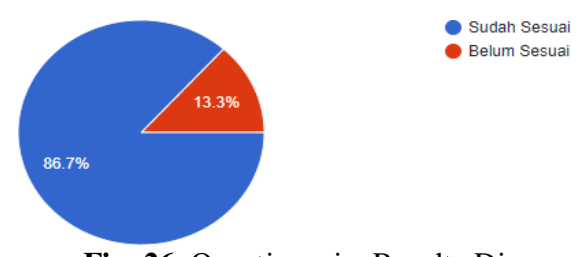

Fig. 26. Questionnaire Results Diagram

The picture above is the result of user responses to prototypes of other payment methods, where there are $86.7 \%$ of users choosing to be suitable and $13.3 \%$ not suitable. 


\section{Conclusions}

After describing the digital strategy above, the following conclusions from this research: To answer the problems identified at Eguards startup, a digital strategy based on the Design Thinking approach is supported by an analysis of the Platform Design Toolkit. Because after an analysis using the Platform Design Toolkit, a value proposition is found for the Eguards business, which is providing security services according to customer needs and also after analyzing using the Design Thinking approach, an application needs analysis is found that matches the customer's desires by using a questionnaire in the Design Thinking approach.

The Design Thinking approach focuses on the Eguards startup application platform from the customer side, it can be concluded that Eguards need to focus on updating their applications which makes it easy for users because the biggest reason users choose the Eguards application compared to other competitor applications is ease, can be seen from Figure 13.

There are three proposed features that the researchers propose in this study which are intended to increase the user convenience of the Eguards application, namely the "chat-on apps" feature, the feature can see the coverage of the Eguards service area and the feature of adding payment methods. This proposed feature was obtained from the researchers' observations, interviews with startups, and responses from Eguards users through questionnaires. 


\section{References}

[1] J. Peppard, J, and Ward, The Strategic Management of Information Systems: Building a Digital Strategy, 4th ed. Wiley, 2016.

[2] J. Tambotoh, "Penerapan Kajian Kelayakan Finansial untuk Meningkatkan Tingkat Kematangan Manajemen Investasi Sistem Informasi/Teknologi Informasi Studi Kasus: PT. PLN (Persero)," Jakarta, 2010.

[3] B. Waspodo, S. Ratnawati, and R. Halifi, "Building Digital Strategy Plan at CV Anugrah Prima, an Information Technology Service Company," 2018 6th Int. Conf. Cyber IT Serv. Manag. CITSM 2018, no. CITSM, pp. 7-10, 2018.

[4] J. W. Ross, I. M. Sebastian, C. Beath, M. Mocker, K. G. Moloney, and N. O. Fonstad, "Designing and executing digital strategies," 2016 Int. Conf. Inf. Syst. ICIS 2016, pp. 1-17, 2016.
[5] Anonym,
"Top
Indonesia."
[Online].
Available:

https://www.startupranking.com/top/indonesia.

[6] Anony m, "Strategic Planning: 5 essential considerations for SME owners," 2013.

[7] G. Stair, Ralph, and Reynold, Principle of Information System, 9th ed. Course-Technology Cengage Learning, USA, 2010.

[8] T. Sutabri, Analisis Sistem Informasi. Yogy akarta: CV. Andi Offset, 2012.

[9] A. Muly anto, Sistem Informasi Konsep dan Aplikasi. Yogy akarta: Pustaka Pelajar, 2009.

[10] C. Matt, T. Hess, and A. Benlian, "Digital Transformation Strategies," Bus. Inf. Syst. Eng., vol. 57, no. 5, pp. 339-343, 2015.

[11] T. Brown, Change by Design: How Design Thinking Transforms Organizations and Inspires Innovation. Harper Collins, England, 2013.

[12] S. Cicero, "Design Toolkit V2," 2017. [Online]. Available: https://platformdesigntoolkit.com. [Accessed: 14-Jun-2019].

[13] Anonym, "Platform." [Online]. Available: https://www.techopedia.com/definition/3411/platform-computing. [Accessed: 17-Jun-2019].

[14] E. Ries, The Lean Startup. Crown Publishing Group, USA, 2011.

[15] P. Graham, "Startup Growth," 2012. [Online]. Available: http://www.paulgraham.com/growth.html. [Accessed: 13-Jul-2018]. 